INTERNATIONAL DESIGN CONFERENCE - DESIGN 2018

https://doi.org/10.21278/idc.2018.0267

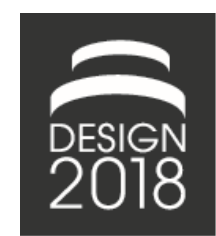

\title{
COMPETITIVE CAPABILITY ASSESSMENT OF INDUSTRIAL COMPANIES WITHIN THE FRAMEWORK OF ADVANCED INNOVATION DESIGN APPROACH
}

\author{
P. Livotov
}

\begin{abstract}
The comprehensive assessment method includes 80 innovation performance parameters and 10 key indicators of innovation capability, such as innovation process performance, innovating system performance, market and customer orientation, technology orientation, creativity, leadership, communication and knowledge management, risk and cost management, innovative climate, and innovation competences. The cross-industry study identifies parameters critical for innovation success and reveals different innovation performance patterns in companies.
\end{abstract}

Keywords: innovation management, empirical studies, product development

\section{Introduction}

The Advanced Innovation Design Approach (AIDA) has been conceptualised as a holistic methodology for enhancing the innovative and competitive capability of industrial companies in the cross-industry research project "Innovation Process 4.0" in Germany from 2015 to 2017 (Livotov, 2016). Its further development for application in the field of process engineering has been continued in the context of the EU research project "Intensified by Design - Platform for the intensification of processes involving solids handling" within the international consortium of 22 universities, research institutes and industrial companies under the H2020 SPIRE programme (Casner and Livotov, 2017). AIDA can now be considered as a new mindset with an individually adaptable range of the strongest innovation design techniques. These include comprehensive front-end innovation process, advanced innovation methods, best tools and methods of the theory of inventive problem solving TRIZ (Altshuller, 1984; VDI, 2016), systematic approaches to design (Pahl and Beitz, 1996), organisational measures for accelerating innovation, and IT-solutions for Computer-Aided Innovation, among other innovation design methods, elaborated over the last decade in the industry and academia (de Bont et al., 2013; Celi, 2014).

As a holistic and systemic approach AIDA supports innovative design process, combining a new product development with optimisation or disruption of the user's working process. The innovation process with self-configuration, self-optimization, self-diagnostics and intelligent information processing and communication, is understood as a holistic system comprising the following typical phases with feedback loops and simultaneous auxiliary or follow-up processes: the uncovering of solution-neutral customer needs, technology and market trends, the identification of the needs and problems with high market potential and formulation of innovation tasks and strategies, systematic idea generation and problem solving, the evaluation and enhancement of solution ideas, the creation of innovation concepts based on solution ideas, the evaluation of these innovation concepts as well as implementation, validation and the market launch of chosen innovation concepts. AIDA postulates the principle of 
completeness in all major process phases, such as innovation strategy formulation, problem analysis and definition, comprehensive idea generation, problem solving and new concept development.

AIDA implementation in companies helps to improve their innovation processes, enhancing their competitive capability and contributing generally to an innovation-friendly climate. The competitive capability of companies is understood as their long-term sustainable ability to maintain the competitive advantages, through both incremental and radical product, process, service or business model innovations with repeatable market success.

However, industrial companies have different needs regarding the optimization of their innovation ability, which may depend on companies' industrial or business sectors, business models, business trends including the financial results, company size and structure, complexity of products, innovation outcomes (product, process, service) and other factors. Thus, an attempt to systematically identify, structure, and evaluate these needs was undertaken, and specific opportunities for further enhancement of innovation and thus of the competitive capabilities of industrial companies were revealed in the presented research study. As a result of these efforts, a method for the comprehensive assessment of the competitive capability of industrial companies, based on evaluation of 80 innovation performance parameters and 10 key indicators has been developed by the interdisciplinary AIDA research consortium and added to the AIDA toolbox.

This work considers a literature review about the critical role of the innovation capability (Noordin and Mohtar, 2013) and is based on the thorough analysis of innovation process management in the industry, and especially in the small and medium enterprises given in (Livotov, 2016). It builds on results of the following research studies and works, mentioned in chronological order: the set of metrics needed for assessing a company's innovativeness, combining three views on innovation - resource, capability, and leadership (Müller et al., 2005), success factors and guidelines in the early stages of the innovation process (Kohn and Wischmann, 2006), the synthesis of successful innovation process models linked to innovation capability factors such as competencies, knowledge exploitation, and organisational support (Du Preez et al., 2006), the controlling model for analysis and optimisation of the company's innovation system (Bürgin, 2007), the definition and empirical study of 28 critical success factors of SME's innovation capability (Kirner et al., 2007), nine general key success factors in new product development (Cooper and Kleinschmidt, 2007), 20 efficiency metrics for innovation and new product development process in industrial companies (Livotov, 2010), innovation indicators proposal for four application areas within the MINT - Measuring Innovation in Teams framework (Nilsson et al., 2010), seven categories with 40 items, characterizing the relationship between innovation capability and performance (Saunila et al., 2014), the principles of holistic enterprise innovation performance measurement system (Dewangan and Godse, 2014), and a definition of innovation metrics, indicators and empowering factors in an industrial case study (Benaim et al., 2015).

\section{Research method}

Systematic mapping of the innovation processes within the research consortium of 10 German industrial companies was done over a period of 12 months. This was achieved in a series of workshops and interviews with CEOs, R\&D leaders and engineers, and by literature analysis in the field of research. The industrial research partners were companies of different sizes and industrial sectors: automation and control systems, automotive engineering, automotive OEM, furniture technology, material application systems, power tools manufacturer, power-train technology, sealing technology, surface technology, and vacuum technology. Half of the partners were medium-sized enterprises.

The comprehensive processing of information allowed for the identification of more than 100 separate problems, tasks, needs or factors for achieving successful innovation, which are subsequently summarised by the 80 innovation performance parameters (IPP). As illustrated in Table 1 and fully presented in the Appendix, the 80 IPPs belong to two general categories, defined as

I. InnoSystem: 50 IPPs, No.1 to No.50, characterizing companies as innovating systems.

II. InnoProcess: 30 IPPs, No. 51 to No. 80, characterizing innovation process established in the companies. 
In order to select IPPs with higher priorities, two parameters - the importance of each IPP and the current satisfaction with its existing performance within the companies - were evaluated by staff members on scale of $0 \%$ (lowest value) to $100 \%$ (highest value), with intervals of $25 \%: 100 \%$ - very high, $75 \%$ high, 50\% -medium, 25\% - low, $0 \%$ - very low. 168 completely anonymously questionnaires from 19 companies with 80 importance and 80 satisfaction questions were retrieved and processed. The importance and satisfaction mean values across a company allowed one to calculate with formula (1) the ranking value $p_{i}$ of each IPP, and two complimentary general metrics:

- total innovating system performance $V_{S}$, based on the corresponding 50 IPPs No. 1 to No. 50

- total innovation process performance $V_{P}$, based on the corresponding 30 IPPs No. 51 to No. 80

Table 1. Innovation performance parameters IPP (example)

\begin{tabular}{|c|l|l|l|}
\hline No. & \multicolumn{1}{|c|}{ Description } & \multicolumn{1}{c|}{ Category } & \multicolumn{1}{c|}{ Assigned indicator } \\
\hline 1 & Senior executives understand innovation process & InnoSystem & 4. Leadership \\
\hline 2 & System of metrics for accountable innovation & InnoSystem & 4. Leadership \\
\hline 17 & Innovation competences of staff members & InnoSystem & 8. Innov. Competences \\
\hline 24 & Contacts with external research institutes & InnoSystem & 2. Technol. orientation \\
\hline$\ldots$ & & & \\
\hline 51 & Prediction of new technologies and technical features & InnoProcess & 2. Technol. orientation \\
\hline 53 & Identification of existing and future customer needs & InnoProcess & 1. Market orientation \\
\hline 80 & Fast and efficient organisational problem-solving & InnoProcess & 4. Leadership \\
\hline
\end{tabular}

The innovation performance parameters with higher importance and lower satisfaction have reasonably higher ranking values $p_{i}$, and thus higher need for action in terms of enhancing innovation and competitive capability. In the formula (1) the ranking $p_{i}$ of each IPP is calculated as a maximal contribution of the IPP to the growth of current total innovation system performance $V_{S}$, or of the total innovation process performance $V_{P}$ in accordance to the universal approach for the importancesatisfaction analysis, presented in (Livotov, 2008):

$$
\left\{\begin{array}{c}
p_{i}=\frac{\left(W_{i}+a W_{i}\left(W_{i}-Z_{i}\right)\right)\left(1-Z_{i}\right)}{\sum_{i=1}^{i=n}\left(W_{i}+a W_{i}\left(W_{i}-Z_{i}\right)\right)} \\
V=\sum_{i=1}^{i=n} \frac{Z_{i}\left(W_{i}+a W_{i}\left(W_{i}-Z_{i}\right)\right)}{\sum_{i=1}^{i=n}\left(W_{i}+a W_{i}\left(W_{i}-Z_{i}\right)\right)}
\end{array}\right.
$$

where:

$p_{i}$ - ranking of the IPP, \%

$V$ - total innovating system performance $V_{S}$ or innovation process performance $V_{P}, \%$

$W_{i}$ - mean importance of IPP, $0 \ldots 100 \%$

$Z_{i}$ - mean satisfaction with current IPP performance, $0 \ldots 100 \%$

$n$ - total number of IPP (here $n=50$ for innovating system or $n=30$ for innovation process)

$a$-adjustment coefficient, $a=1$ in case of the equal weighting of importance $W_{i}$ and satisfaction $Z_{i}$

Moreover, each IPP can be assigned to one of the following 8 innovation indicators: Market and customer orientation, Technology orientation, Creativity, Leadership, Communication and knowledge management, Risk and cost management, Innovative climate, and Innovation competences, as presented in Table 2 and the Appendix. The value of the innovation indicators $I_{1}$ to $I_{8}$ is defined as a mean satisfaction value of the assigned IPPs. For example, the value of the innovation indicator 1. Market and customer orientation is calculated with the formula (2) in accordance to its definition in the Table 2 and with the satisfaction values $Z_{i}$ of the assigned IPPs presented in Table 3:

$$
I_{1}=\left(Z_{26}+Z_{27}+Z_{28}+Z_{42}+Z_{49}+Z_{50}+Z_{53}+Z_{54}+Z_{55}\right) / k
$$

where:

$Z i$ - mean satisfaction with performance of the IPPs No. 26, 27, 28, 29, 42, 49, 50, 53, 54, 55, in \%

$k$ - amount of IPPs assigned to the innovation indicator; here $k=10$ 
Table 2. Innovation indicators with the assigned IPPs

\begin{tabular}{|c|l|c|}
\hline No & \multicolumn{1}{|c|}{ Innovation Indicator } & $\begin{array}{c}\text { No. of assigned innovation performance } \\
\text { parameters IPP }\end{array}$ \\
\hline 1 & Market and customer orientation & $26,27,28,29,42,49,50,53,54,55$ \\
\hline 2 & Technology orientation & $24,25,34,40,48,51,52,56$ \\
\hline 3 & Creativity & $15,37,38,39,43,44,45,46,58,59$ \\
\hline 4 & Leadership & $1,2,3,4,11,23,47,80$ \\
\hline 5 & Communication \& knowledge management & $30,31,32,33,41,57,60,62,64,69,70,72,74$ \\
\hline 6 & Risk and cost management & $63,65,66,67,68,71,73,75,76,77,78,79$ \\
\hline 7 & Innovative climate & $7,8,9,10,12,13,14,16$ \\
\hline 8 & Innovation competences & $5,6,17,18,19,20,21,22,35,36$ \\
\hline
\end{tabular}

Table 3. Innovation indicator 1. Market and customer orientation

\begin{tabular}{|c|l|c|}
\hline $\begin{array}{c}\text { IPP } \\
\text { No }\end{array}$ & \multicolumn{1}{|c|}{ Assigned innovation performance parameter (IPP) } & $\begin{array}{c}\text { Satisfaction with IPP } \\
\text { performance Zi * }\end{array}$ \\
\hline 26 & $\begin{array}{l}\text { Customers involvement in entire innovation process, from capturing } \\
\text { customer needs to the market launch of new products. }\end{array}$ & $63,0 \%$ \\
\hline 27 & $\begin{array}{l}\text { Systematic collection, evaluation and implementation of customer } \\
\text { feedback, in the form of complaints, suggestions and ideas. }\end{array}$ & $62,2 \%$ \\
\hline 28 & $\begin{array}{l}\text { Systematic review of customer acceptance of new technologies, products } \\
\text { or services before market launch. }\end{array}$ & $60,1 \%$ \\
\hline 29 & $\begin{array}{l}\text { Convincing market communication, with the explanation of all customer } \\
\text { benefits in new product launches. }\end{array}$ & $66,7 \%$ \\
\hline 42 & $\begin{array}{l}\text { Preferred tracking and implementation of ideas with particularly high } \\
\text { customer value. }\end{array}$ & $73,2 \%$ \\
\hline 49 & $\begin{array}{l}\text { Our company understands the customers' innovation process well: we } \\
\text { know how our customers innovate and what challenges they face. }\end{array}$ & $60,5 \%$ \\
\hline 50 & Our customers understand the innovation process in our company well. \\
\hline 53 & $\begin{array}{l}\text { Complete identification of existing and new customer requirements and } \\
\text { needs. }\end{array}$ & $\begin{array}{l}\text { Identification of the strongest product or service characteristics with } \\
\text { highest market potential or market acceptance. }\end{array}$ \\
\hline 55 & $\begin{array}{l}\text { Monitoring competitive activities in the market and identification of the } \\
\text { main competitive features. }\end{array}$ & $55,4 \%$ \\
\hline $\mathbf{1 .}$ Market and customer orientation - estimation example with formula $(2)$ & $59,9 \%$ \\
\hline
\end{tabular}

*) cross-industry mean values based on $n=168$ questionnaires received from 19 companies

Additionally, for each innovation performance parameter a segment analysis of the importance and satisfaction opinions from staff members in the companies can be performed in accordance with following procedure, described in (Livotov, 2008):

- segment 1: percentage of opinions with high importance ( $\geq 75 \%)$ and high satisfaction $(\geq 75 \%)$,

- segment 2: percentage of opinions with high importance $(\geq 75 \%)$ and low satisfaction $(\leq 50 \%)$,

- segment 3: percentage of opinions with low importance $(\leq 50 \%)$ and high satisfaction $(\geq 75 \%)$,

- segment 4: percentage of opinions with low importance $(\leq 50 \%)$ and low satisfaction $(\leq 50 \%)$.

It is a simple and transparent evaluation mechanism, which complements the actual evaluation based on mean values of importance $W_{i}$ and satisfaction $Z_{i}$. It enables the identification of groups of staff members (group size, department) with similar priorities in the innovation process, and to anticipate potential conflicts of interest. For example, the IPPs in segment 1 are well-served and don't require urgent improvement efforts. The IPPs in segment 3 are currently over-served, and in segment 4 they are 
irrelevant, i.e. without significant need for action. The IPPs in the critical segment 2 are characterised by high importance and low performance, and therefore should be put into the focus of improvement actions. In addition to the statistically estimated ranking $p_{i}$, the highest size values $S_{i}$ of the segment 2 help to pick critical IPPs directly, as shown in Table 4 and Table 5.

\section{Discussion of results}

Analysis of the in-depth interviews and workshops with 10 consortium partners and the outcomes of the cross-industry survey with 168 participants from 19 companies in 2016-17 allow us to assume that the competitive capability and innovation success of the companies depend up to $65 \%$ on organisational factors (50 IPPs in category InnoSystem) and up to $35 \%$ on technological or methodological competences (30 IPP in category InnoProcess). Table 4 and Table 5 illustrate the results of the importance-satisfaction analysis for the corresponding innovating system and innovation process. They show the mean values for the top 5 innovation performance factors for the InnoSystem and InnoProcess categories respectively. These 10 IPPs from a total of 80 can be considered critical for enhancement of competitive and innovation capability, on average, across all companies. The individual analysis of companies shows that each company has its specific priorities and set of innovation performance parameters critical for the improvement of innovation capability.

Table 4. Top 5 innovation performance parameters (IPP) of the innovating system

\begin{tabular}{|c|l|c|c|c|c|}
\hline No. & Innovation performance parameter (IPP) & $\begin{array}{c}\text { Ranking } \\
\text { pi [\%] }\end{array}$ & $\begin{array}{c}\text { Importance } \\
\text { Wi }\end{array}$ & $\begin{array}{c}\text { Satisfaction } \\
\mathbf{Z i}\end{array}$ & $\begin{array}{c}\text { Critical } \\
\text { segment Si }\end{array}$ \\
\hline 13 & $\begin{array}{l}\text { Strong non-commercial motivation of } \\
\text { engineers and employees for innovative } \\
\text { ideas, e.g. through awards. }\end{array}$ & 1,09 & $70 \%$ & $44 \%$ & $47 \%$ \\
\hline 46 & $\begin{array}{l}\text { Continuous development and } \\
\text { implementation of measures that enhance } \\
\text { creativity and innovation. }\end{array}$ & 1,03 & $75 \%$ & $51 \%$ & $63 \%$ \\
\hline 8 & $\begin{array}{l}\text { Employees can devote some of their time to } \\
\text { their own innovative projects that have not } \\
\text { yet officially started. }\end{array}$ & 1,03 & $78 \%$ & $53 \%$ & $55 \%$ \\
\hline 38 & $\begin{array}{l}\text { Regular meetings of cross-departmental } \\
\text { expert teams to generate novel ideas and } \\
\text { inventively solve problems. }\end{array}$ & 1,02 & $74 \%$ & $50 \%$ & $51 \%$ \\
\hline 6 & $\begin{array}{l}\text { Many employees in various departments } \\
\text { actively promote innovation and drive it } \\
\text { forward. }\end{array}$ & 1,00 & $83 \%$ & $57 \%$ & $55 \%$ \\
\hline
\end{tabular}

cross-industry mean values based on $n=168$ questionnaires received from 19 companies

The mean values of the total innovating system performance $V_{S}$ and total innovation process performance $V_{P}$ amounts to $V_{S}=62,8 \%$ and $V_{P}=58,8 \%$ correspondingly. No assessed industrial company could reach a maturity level of $75 \%$ (lower bound of high performance) for both metrics. A moderate statistically significant positive correlation with Pearson $r=0,62(p<0,01)$ between both performance values $V_{S}$ and $V_{P}$ was observed for 19 companies.

The average values of the innovation indicators across the participants of the study are presented in Table 6. Also, no industrial company can reach a maturity level of $75 \%$ for any metric. For the entire data $(n=168)$, a strong positive correlation can be observed between the Leadership and the Innovation Competences $(r=0,80, p<0,01)$, the Leadership and Creativity $(r=0,82, p<0,01)$ and between the Innovation Competences and the Creativity $(r=0,87, p<0,01)$. The correlation between the Innovating climate and the Creativity with Pearson $r=0,60(p<0,01)$ is somewhat moderate.

Similar to the outcomes of the earlier empirical innovation study (Kirner et al., 2007), no statistically significant difference in IPP importance and satisfaction values of SMEs with less than 500 employees and of large enterprises can be extracted from the results. 
Table 5. Top 5 innovation performance parameters (IPP) of the innovation process

\begin{tabular}{|c|l|c|c|c|c|}
\hline No. & \multicolumn{1}{|c|}{ Innovation performance parameter (IPP) } & $\begin{array}{c}\text { Ranking } \\
\text { pi [\%] }\end{array}$ & $\begin{array}{c}\text { Importance } \\
\mathbf{W i}\end{array}$ & $\begin{array}{c}\text { Satisfaction } \\
\mathbf{Z i}\end{array}$ & $\begin{array}{c}\text { Critical } \\
\text { segment Si }\end{array}$ \\
\hline 53 & $\begin{array}{l}\text { Complete identification of existing and new } \\
\text { customer requirements and needs. }\end{array}$ & 1,90 & $86 \%$ & $55 \%$ & $56 \%$ \\
\hline 72 & $\begin{array}{l}\text { Seamless information exchange and transparent } \\
\text { communication in innovation process. }\end{array}$ & 1,86 & $84 \%$ & $55 \%$ & $60 \%$ \\
\hline 80 & $\begin{array}{l}\text { Quick and efficient solving of organizational } \\
\text { problems in the innovation process. }\end{array}$ & 1,78 & $83 \%$ & $55 \%$ & $58 \%$ \\
\hline 52 & $\begin{array}{l}\text { Cross-industry tracking of new technological } \\
\text { trends and technologies transfer. }\end{array}$ & 1,58 & $82 \%$ & $59 \%$ & $52 \%$ \\
\hline 65 & $\begin{array}{l}\text { Anticipatory early identification of technical } \\
\text { problems and risks in new ideas or concepts. }\end{array}$ & 1,56 & $83 \%$ & $59 \%$ & $52 \%$ \\
\hline
\end{tabular}

cross-industry mean values based on $n=168$ questionnaires received from 19 companies

Table 6. Innovation indicators and their mean values across the industry

\begin{tabular}{|c|l|c|}
\hline No & \multicolumn{1}{|c|}{ Innovation indicator } & Mean value \\
\hline 1 & Market and customer orientation & $60,7 \%$ \\
\hline 2 & Technology orientation & $62,4 \%$ \\
\hline 3 & Creativity & $58,7 \%$ \\
\hline 4 & Leadership & $62,5 \%$ \\
\hline 5 & Communication and knowledge management & $59,6 \%$ \\
\hline 6 & Risk and cost management & $59,2 \%$ \\
\hline 7 & Innovative climate & $63,3 \%$ \\
\hline 8 & Innovation competences & $63,7 \%$ \\
\hline
\end{tabular}

The results of the study reveal different innovation performance patterns and correlation of innovation indicators in companies as illustrated in Figure 1 and Figure 2. The below-average numbers of innovation indicators are often observed in cases of low leadership value.

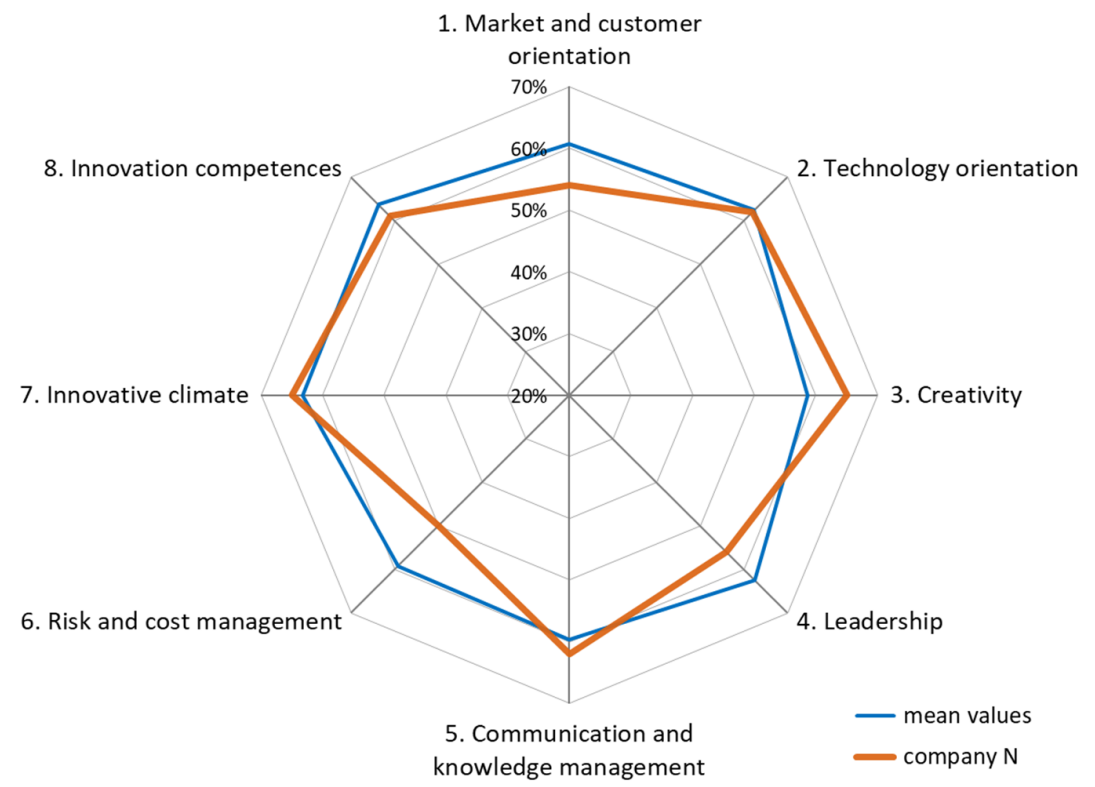

Figure 1. Example of innovation indicators of one company (orange polygon) in comparison with average values in the industry (blue polygon) 


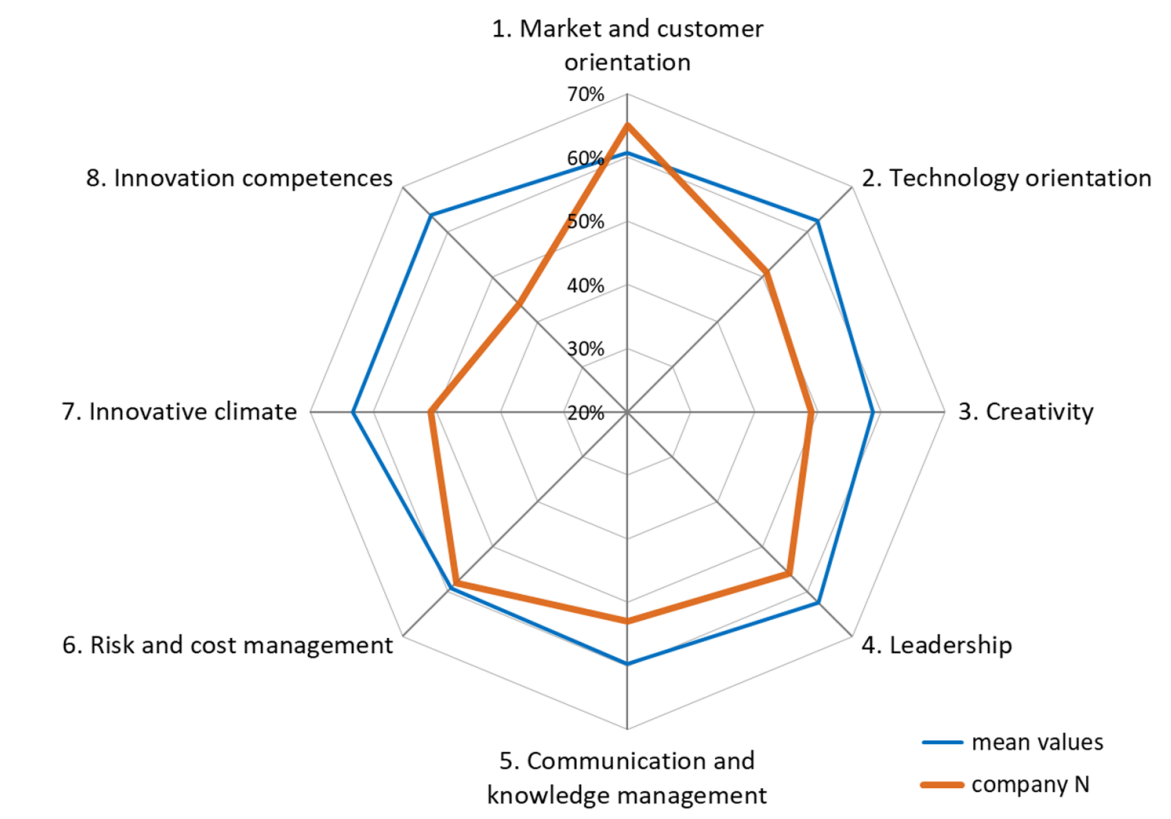

Figure 2. Example of innovation indicators of one company (orange polygon) in comparison with average values in the industry (blue polygon)

The innovation performance of companies in terms of innovation indicators values is often unbalanced, and typically only shows one or two strong features, as shown in the Figure 2. Another statistical observation confirms that established risks and cost management in the companies can moderately correlate with lower value of the innovative climate.

\section{Conclusion and outlook}

The evaluation of the company self-assessments has shown that each company has a unique scope of urgent measures to enhance its innovation capability. Due to the results obtained, company's executives and engineers can see that they often overestimate their actual innovation performance and perhaps do not even know or monitor the relevant performance parameters or indicators. The application of the proposed method for the practice allows the targeted enhancement of innovative capability and helps to establish a well-structured and comprehensive approach in managing innovation.

The objective of the presented research work is to develop a holistic assessment method for revealing opportunities for the fast and systematic enhancement of innovation and competitive capabilities of industrial companies, making this process more systematic, measurable, and controllable.

Additionally, the list of innovation performance parameters and indicators can be extended in the future with new aspects, such as parameters relevant for process innovation and business model innovation or for issues regarding the innovation impact of suppliers and service innovation.

Finally, a developed database of standard measures, best practices and tools for realisation of the identified opportunities for enhancement of innovation capability can be supplemented and evaluated through practical application in the context of the Advanced Innovation Design Approach.

\section{References}

Altshuller, G.S. (1984), Creativity as an Exact Science. The Theory of the Solution of Inventive Problems, Gordon $\&$ Breach Science Publishers, NY.

Benaim, A., Elfsberg, J., Larsson, T.C. and Larsson, A. (2015), "Implementing Innovation Metrics: A case study", Proceedings of the 20th International Conference on Engineering Design (ICED 15), July 27-30, 2015, Milan, Italy.

de Bont, C., den Ouden, P.H., Schifferstein, H.N.J., Smulders, F.E.H.M. and van der Voort, M. (2013), Advanced design methods for successful innovation, Design United, Den Haag.

Bürgin, C. (2007), Reifegradmodell zur Kontrolle des Innovationssystems von Unternehmen, PhD thesis, ETH Zurich. 
Casner, D. and Livotov, P. (2017), “Advanced innovation design approach for process engineering”, Proceedings of the 21st International Conference on Engineering Design (ICED 17) Vancouver, Canada, August 21-25, 2017, pp. 653-662.

Celi, M. (2014), Advanced design cultures: Long-term perspective and continuous innovation, Springer International Publishing, Switzerland, https://doi.org/10.1007/978-3-319-08602-6

Cooper, R. and Kleinschmidt, E. (2007), "Winning businesses in product development: The critical success factors", Research - Technology Management, Vol. $50 \quad$ No. 3, pp. 52-66. https://doi.org/10.1080/08956308.2007.11657441

Dewangan, V. and Godse, M. (2014), "Towards a holistic enterprise innovation performance measurement system”, Technovation, Vol. 34 No. 9, pp. 536-545. https://doi.org/10.1016/j.technovation.2014.04.002

Du Preez, N., Louw, L. and Essmann, H. (2006), "An Innovation Process Model for Improving Innovation Capability”, Journal of High Technology Management Research, Vol. 17, pp. 1-24.

Kirner, E., Maloca S., Rogowski T., Slama, A., Som, O. et al. (2007), Kritische Erfolgsfaktoren zur Steigerung der Innovationsfähigkeit. Empirische Studie bei produzierenden KMU, Fraunhofer-Institut für Arbeitswirtschaft und Organisation IAO und Universität Stuttgart, Institut für Arbeitswissenschaft und Technologiemanagement IAT, Stuttgart.

Kohn, S. and Wischmann, W. (2006), Innovation in place of Stagnation. Success factors in innovation process. [online], Fraunhofer Technology Development Group, Stuttgart, Germany. Available at: http://publica.fraunhofer.de/dokumente/N-53673.html (accessed 15.01.2016).

Livotov, P. (2008), "Method for Quantitative Evaluation of Innovation Tasks for Technical Systems, Products and Processes", Proceedings of ETRIA World Conference 2008 "Synthesis in Innovation", University of Twente, Enschede, The Netherlands, November 5 - 7, 2008, pp. 197-199.

Livotov, P. (2010), "Measuring efficiency of innovation and new product development process in industrial companies - analysis of current situation, tendencies and identification of opportunities for enhancement", Proceedings of the 10th ETRIA World Conference, Bergamo, November 3 - 5, 2010, Bergamo University Press, pp. 311-312.

Livotov, P. (2016), "Systemic Approach for Enhancing Innovative and Competitive Capability of Industrial Companies - Research Concept", Journal of the European TRIZ Association, Vol. 2 No. 2, pp. 163-169.

Müller, A., Välikangas, L. and Merlyn, P. (2005), "Metrics for innovation: guidelines for developing a customized suite of innovation metrics", Strategy and Leadership, Vol. 33 No. 1, pp. 37-45. https://doi.org/10.1108/10878570510572590

Nilsson, F., Regnell, B., Larsson, T. and Ritzén, S. (2010), Measuring for Innovation, Applied Innovation Management, Sweden.

Noordin, M.A. and Mohtar, S. (2013), "Innovation Capability: A Critical Review of its Role in Determining Firm Performance", Research Journal of Social Science and Management, Vol. 3 No. 4, pp. 220-226.

Pahl, G. and Beitz, W. (1996), Engineering Design: A Systematic Approach, Springer, Berlin. https://doi.org/10.1007/978-1-4471-3581-4

Saunila, M., Pekkola, S. and Ukko, J. (2014), "The relationship between innovation capability and performance: The moderating effect of measurement", International Journal of Productivity and Performance Management, Vol. 63 No. 2, pp. 234-249. https://doi.org/10.1108/IJPPM-04-2013-0065

VDI (2016), VDI Standard 4521. Inventive problem solving with TRIZ. Fundamentals, terms and definitions, VDI, Berlin. 


\section{Appendix: 80 innovation performance parameters, categories and assigned innovation indicators with estimated importance $W_{i}$, satisfaction $Z_{i}$ and ranking values $p_{i}$}

(cross-industry mean values based on $n=168$ questionnaires from 19 companies).

\begin{tabular}{|c|c|c|c|c|c|c|}
\hline No. & Innovation Performance Parameters - IPP & Category & $\begin{array}{c}\text { Innovation } \\
\text { Indicator }\end{array}$ & \begin{tabular}{|c|} 
Imp. \\
Wi \\
\end{tabular} & $\begin{array}{c}\text { Sat. } \\
\text { Zi } \\
\end{array}$ & $\begin{array}{l}\text { Rank. } \\
\text { pi [\%] }\end{array}$ \\
\hline 1 & $\begin{array}{l}\text { Executives understand the innovation process, its } \\
\text { individual phases and subtasks in detail. }\end{array}$ & InnoSystem & 4. Leadership & $77 \%$ & $67 \%$ & 0,63 \\
\hline 2 & $\begin{array}{l}\text { The success of innovation projects is measurable and } \\
\text { belongs to the most important corporate indicators. }\end{array}$ & InnoSystem & 4. Leadership & $69 \%$ & $52 \%$ & 0,85 \\
\hline 3 & $\begin{array}{l}\text { Executives support and personally promote } \\
\text { innovation in the company. }\end{array}$ & InnoSystem & 4. Leadership & $89 \%$ & $71 \%$ & 0,69 \\
\hline 4 & $\begin{array}{l}\text { The executives have a very high willingness for } \\
\text { theapplication of new technologies, development of } \\
\text { new markets, etc. }\end{array}$ & InnoSystem & 4. Leadership & $91 \%$ & $73 \%$ & 0,65 \\
\hline 5 & $\begin{array}{l}\text { Many employees in various departments understand } \\
\text { the innovation process, its individual phases, and } \\
\text { subtasks. }\end{array}$ & InnoSystem & $\begin{array}{l}\text { 8. Innovation } \\
\text { competences }\end{array}$ & $78 \%$ & $54 \%$ & 0,99 \\
\hline 6 & $\begin{array}{l}\text { Many employees in various departments actively } \\
\text { promote innovation and drive it forward. }\end{array}$ & InnoSystem & $\begin{array}{l}\text { 8. Inn } \\
\text { comp }\end{array}$ & $83 \%$ & $57 \%$ & 1,00 \\
\hline 7 & $\begin{array}{l}\text { Flexible individual working conditions and results- } \\
\text { oriented performance evaluation of employees and } \\
\text { staff members. }\end{array}$ & InnoSystem & $\begin{array}{l}\text { 7. Innovating } \\
\text { climate }\end{array}$ & $73 \%$ & $60 \%$ & 0,75 \\
\hline 8 & $\begin{array}{l}\text { Employees can devote some of their time to their } \\
\text { own innovative ideas or projects that have not yet } \\
\text { officially started. }\end{array}$ & InnoSystem & $\begin{array}{l}\text { 7. Innovating } \\
\text { climate }\end{array}$ & $78 \%$ & $53 \%$ & 1,03 \\
\hline 9 & $\begin{array}{l}\text { lways welcome to contribute ideas } \\
\text { to the innovation projects. }\end{array}$ & InnoSystem & $\begin{array}{l}\text { 7. Innovating } \\
\text { climate }\end{array}$ & $92 \%$ & $79 \%$ & 0,48 \\
\hline 10 & $\begin{array}{l}\text { ways welcome to include critical } \\
\text { ncerns in innovation projects. }\end{array}$ & Inno & $\begin{array}{l}\text { 7. Innovating } \\
\text { climate }\end{array}$ & $88 \%$ & $75 \%$ & 0,56 \\
\hline 11 & $\begin{array}{l}\text { Short and fast decision-making in innovation } \\
\text { projects. }\end{array}$ & InnoSystem & 4. Leadership & $82 \%$ & $63 \%$ & 0,80 \\
\hline 12 & $\begin{array}{l}\text { Promotion of innovative ideas of employees through } \\
\text { financial incentives. }\end{array}$ & InnoSystem & $\begin{array}{l}\text { 7. Innovating } \\
\text { climate }\end{array}$ & $70 \%$ & $57 \%$ & 0,77 \\
\hline 13 & $\begin{array}{l}\text { Strong non-commercial motivation of engineers and } \\
\text { employees for innovative ideas, e.g. through awards. }\end{array}$ & InnoSystem & $\begin{array}{l}\text { 7. Innovating } \\
\text { climate }\end{array}$ & $70 \%$ & $44 \%$ & 1,09 \\
\hline 14 & $\begin{array}{l}\text { Innovation is part of the mission statement of a } \\
\text { company and its corporate strategy. }\end{array}$ & InnoSystem & $\begin{array}{l}\text { 7. Innovating } \\
\text { climate }\end{array}$ & $87 \%$ & $75 \%$ & 0,54 \\
\hline 15 & $\begin{array}{l}\text { A high degree of commitment and proactive thinking } \\
\text { among employees. }\end{array}$ & InnoSystem & 3. Creativity & $84 \%$ & $69 \%$ & 0,68 \\
\hline 16 & $\begin{array}{l}\text { Available budget for pre-development and research } \\
\text { projects that are not funded by customer orders. }\end{array}$ & InnoSystem & $\begin{array}{l}\text { 7. Innovating } \\
\text { climate }\end{array}$ & $84 \%$ & $63 \%$ & 0,85 \\
\hline 17 & $\begin{array}{l}\text { Technical competences of the employees required in } \\
\text { innovation projects. }\end{array}$ & InnoSystem & $\begin{array}{l}\text { 8. Innovation } \\
\text { competences }\end{array}$ & $86 \%$ & $75 \%$ & 0,54 \\
\hline 18 & $\begin{array}{l}\text { Social competences of the employees required in } \\
\text { innovation projects, like communicative or team- } \\
\text { working skills. }\end{array}$ & InnoSystem & $\begin{array}{l}\text { 8. Innovation } \\
\text { competences }\end{array}$ & $80 \%$ & $71 \%$ & 0,56 \\
\hline 19 & $\begin{array}{l}\text { Methodological competences of the employees } \\
\text { required in innovation projects, such as innovation } \\
\text { methods or techniques. }\end{array}$ & InnoSystem & $\begin{array}{l}\text { 8. Innovation } \\
\text { competences }\end{array}$ & $76 \%$ & $64 \%$ & 0,69 \\
\hline 20 & $\begin{array}{l}\text { Targeted and systematic personnel development in } \\
\text { the field of innovation. }\end{array}$ & InnoSystem & $\begin{array}{l}\text { 8. Innovation } \\
\text { competences }\end{array}$ & $79 \%$ & $59 \%$ & 0,88 \\
\hline 21 & $\begin{array}{l}\text { Many employees in different divisions are ready to } \\
\text { acquire new competencies and skills related to the } \\
\text { innovation process. }\end{array}$ & InnoSyst & $\begin{array}{l}\text { 8. Innovation } \\
\text { competences }\end{array}$ & $72 \%$ & $66 \%$ & 0,58 \\
\hline
\end{tabular}




\begin{tabular}{|c|c|c|c|c|c|c|}
\hline No. & Innovation Performance Parameters - IPP & Category & $\begin{array}{c}\text { Innovation } \\
\text { Indicator }\end{array}$ & $\begin{array}{c}\text { Imp. } \\
\text { Wi }\end{array}$ & $\begin{array}{c}\text { Sat. } \\
\mathbf{Z i}\end{array}$ & $\begin{array}{l}\text { Rank. } \\
\text { pi [\%] }\end{array}$ \\
\hline 22 & $\begin{array}{l}\text { Innovation project teams are constituted by the } \\
\text { employees with required qualifications. }\end{array}$ & InnoSystem & $\begin{array}{l}\text { 8. Innovation } \\
\text { competences }\end{array}$ & $80 \%$ & $67 \%$ & 0,66 \\
\hline 23 & $\begin{array}{l}\text { Executives support and promote teamwork } \\
\text { throughout the duration of innovation projects. }\end{array}$ & InnoSystem & 4. Leadership & $84 \%$ & $66 \%$ & 0,76 \\
\hline 24 & $\begin{array}{l}\text { Regular dialogue with external research and } \\
\text { development organisations. }\end{array}$ & InnoSystem & $\begin{array}{l}\text { 2. Technology } \\
\text { orientation }\end{array}$ & $74 \%$ & $65 \%$ & 0,62 \\
\hline 25 & $\begin{array}{l}\text { Regular contacts in the field of innovation with other } \\
\text { companies in other industrial sectors or with } \\
\text { suppliers. }\end{array}$ & InnoSystem & $\begin{array}{l}\text { 2. Technology } \\
\text { orientation }\end{array}$ & $68 \%$ & $61 \%$ & 0,63 \\
\hline 26 & $\begin{array}{l}\text { Customers involvement in entire innovation process, } \\
\text { from capturing customer needs to the market launch } \\
\text { of new products. }\end{array}$ & InnoSystem & $\begin{array}{l}\text { 1. Market and } \\
\text { customer } \\
\text { orientation }\end{array}$ & $76 \%$ & $63 \%$ & 0,72 \\
\hline 27 & $\begin{array}{l}\text { Systematic collection, evaluation, and } \\
\text { implementation of customer feedback, in the form of } \\
\text { complaints, suggestions or ideas. }\end{array}$ & InnoSystem & $\begin{array}{l}\text { 1. Market and } \\
\text { customer } \\
\text { orientation }\end{array}$ & $80 \%$ & $62 \%$ & 0,79 \\
\hline 28 & $\begin{array}{l}\text { Systematic review of customer acceptance of new } \\
\text { technologies, products or services before market } \\
\text { launch. }\end{array}$ & InnoSystem & $\begin{array}{l}\text { 1. Market and } \\
\text { customer } \\
\text { orientation }\end{array}$ & $80 \%$ & $60 \%$ & 0,86 \\
\hline 29 & $\begin{array}{l}\text { Convincing market communication with the } \\
\text { explanation of all customer benefits in new product } \\
\text { launches. }\end{array}$ & InnoSystem & $\begin{array}{l}\text { 1. Market and } \\
\text { customer } \\
\text { orientation }\end{array}$ & $85 \%$ & $67 \%$ & 0,75 \\
\hline 30 & $\begin{array}{l}\text { Open communication of the goals and tasks of } \\
\text { innovation projects between all those involved in a } \\
\text { company. }\end{array}$ & InnoSystem & $\begin{array}{l}\text { 5. Communication } \\
\text { and knowledge } \\
\text { management }\end{array}$ & $85 \%$ & $64 \%$ & 0,84 \\
\hline 31 & $\begin{array}{l}\text { Open information exchange for problems; failures in } \\
\text { innovation projects are not penalized. }\end{array}$ & InnoSystem & \begin{tabular}{|l|} 
5. Communication \\
and knowledge \\
management
\end{tabular} & $88 \%$ & $70 \%$ & 0,71 \\
\hline 32 & $\begin{array}{l}\text { Learning from mistakes in innovation projects, to } \\
\text { avoid the repetition of past mistakes. }\end{array}$ & InnoSystem & $\begin{array}{l}\text { 5. Communication } \\
\text { and knowledge } \\
\text { management }\end{array}$ & $87 \%$ & $65 \%$ & 0,84 \\
\hline 33 & $\begin{array}{l}\text { Taking the interests of various divisions, such as } \\
\text { marketing, R\&D, production, sales, service, etc. into } \\
\text { account at an early stage of the innovation projects }\end{array}$ & InnoSystem & \begin{tabular}{|l|} 
5. Communication \\
and knowledge \\
management
\end{tabular} & $72 \%$ & $58 \%$ & 0,78 \\
\hline 34 & $\begin{array}{l}\text { External experts confirm the future sustainability of } \\
\text { technologies used in the company. }\end{array}$ & InnoSystem & $\begin{array}{l}\text { 2. Technology } \\
\text { orientation }\end{array}$ & $60 \%$ & $66 \%$ & 0,42 \\
\hline 35 & $\begin{array}{l}\text { Clearly defined criteria for evaluating and selecting } \\
\text { concrete ideas or proposals for implementation. }\end{array}$ & InnoSystem & $\begin{array}{l}\text { 8. Innovation } \\
\text { competences }\end{array}$ & $76 \%$ & $59 \%$ & 0,80 \\
\hline 36 & $\begin{array}{l}\text { Consistent pursuit of innovation goals and } \\
\text { implementation of selected ideas, even if there are } \\
\text { initial difficulties or problems. }\end{array}$ & InnoSystem & $\begin{array}{l}\text { 8. Innovation } \\
\text { competences }\end{array}$ & $84 \%$ & $64 \%$ & 0,81 \\
\hline 37 & $\begin{array}{l}\text { Regular use of brainstorming or other creativity } \\
\text { techniques in the search for new ideas and solutions. }\end{array}$ & InnoSystem & 3. Creativity & $75 \%$ & $61 \%$ & 0,74 \\
\hline 38 & $\begin{array}{l}\text { Regular meetings of cross-departmental expert teams } \\
\text { to generate novel ideas and creatively solve problems. }\end{array}$ & InnoSystem & 3. Creativity & $74 \%$ & $50 \%$ & 1,02 \\
\hline 39 & $\begin{array}{l}\text { Continuous generation and implementation of new } \\
\text { ideas regarding new products or new services in the } \\
\text { company }\end{array}$ & InnoSystem & 3. Creativity & $81 \%$ & $63 \%$ & 0,79 \\
\hline 40 & $\begin{array}{l}\text { Continuous generation and implementation of ideas } \\
\text { regarding new available production methods or } \\
\text { technologies. }\end{array}$ & InnoSystem & $\begin{array}{l}\text { 2. Technology } \\
\text { orientation }\end{array}$ & $76 \%$ & $61 \%$ & 0,76 \\
\hline 41 & $\begin{array}{l}\text { Continuous generation and implementation of ideas } \\
\text { regarding better communication, knowledge, and } \\
\text { information systems in the company. }\end{array}$ & InnoSystem & \begin{tabular}{|l|} 
5. Communication \\
and knowledge \\
management
\end{tabular} & $73 \%$ & $55 \%$ & 0,86 \\
\hline 42 & $\begin{array}{l}\text { Preferred tracking and implementation of ideas with } \\
\text { particularly high customer value. }\end{array}$ & InnoSystem & $\begin{array}{l}\text { 1. Market and } \\
\text { customer } \\
\text { orientation }\end{array}$ & $83 \%$ & $73 \%$ & 0,55 \\
\hline
\end{tabular}




\begin{tabular}{|c|c|c|c|c|c|c|}
\hline No. & Innovation Performance Parameters - IPP & Category & $\begin{array}{l}\text { Innovation } \\
\text { Indicator }\end{array}$ & $\begin{array}{c}\text { Imp. } \\
\text { Wi }\end{array}$ & $\begin{array}{c}\text { Sat. } \\
\text { Zi }\end{array}$ & $\begin{array}{l}\text { Rank. } \\
\text { pi [\%] }\end{array}$ \\
\hline 43 & $\begin{array}{l}\text { One or only a few particularly creative colleagues or } \\
\text { inventors propose the most novel ideas. }\end{array}$ & InnoSystem & 3. Creativity & $54 \%$ & $66 \%$ & 0,36 \\
\hline 44 & $\begin{array}{l}\text { Regular creativity workshops with customers, } \\
\text { external partners, suppliers. }\end{array}$ & InnoSystem & 3. Creativity & $59 \%$ & $45 \%$ & 0,83 \\
\hline 45 & $\begin{array}{l}\text { Search for new creative ideas without restrictions or } \\
\text { limits: everything is conceivable. }\end{array}$ & InnoSystem & 3. Creativity & $77 \%$ & $63 \%$ & 0,72 \\
\hline 46 & $\begin{array}{l}\text { Continuous development and implementation of } \\
\text { measures that enhance or promote creativity and } \\
\text { innovation. }\end{array}$ & InnoSystem & 3. Creativity & $75 \%$ & $51 \%$ & 1,03 \\
\hline 47 & $\begin{array}{l}\text { Coordination and support of the innovation process } \\
\text { and innovation projects by innovation manager or } \\
\text { innovation management department. }\end{array}$ & InnoSystem & 4. Leadership & $66 \%$ & $53 \%$ & 0,80 \\
\hline 48 & $\begin{array}{l}\text { Continuous and systematic research activities, basic } \\
\text { developments, new product or process developments. }\end{array}$ & InnoSystem & $\begin{array}{l}\text { 2. Technology } \\
\text { orientation }\end{array}$ & $81 \%$ & $64 \%$ & 0,77 \\
\hline 49 & $\begin{array}{l}\text { Our company understands the customers innovation } \\
\text { process well: we know how our customers innovate } \\
\text { and what challenges they face. }\end{array}$ & InnoSystem & $\begin{array}{l}\text { 1. Market and } \\
\text { customer } \\
\text { orientation }\end{array}$ & $72 \%$ & $61 \%$ & 0,71 \\
\hline 50 & $\begin{array}{l}\text { Our customers understand the innovation process in } \\
\text { our company well. }\end{array}$ & InnoSystem & $\begin{array}{l}\text { 1. Market and } \\
\text { customer } \\
\text { orientation }\end{array}$ & $51 \%$ & $50 \%$ & 0,59 \\
\hline 51 & $\begin{array}{l}\text { Precise technology forecasts future technical or } \\
\text { technological product characteristics in own business } \\
\text { field. }\end{array}$ & InnoProcess & $\begin{array}{l}\text { 2. Technology } \\
\text { orientation }\end{array}$ & $83 \%$ & $60 \%$ & 1,54 \\
\hline 52 & $\begin{array}{l}\text { Cross-industry tracking of new technological trends } \\
\text { and solutions to transfer and lever new technologies } \\
\text { from other industries and from research. }\end{array}$ & InnoProcess & $\begin{array}{l}\text { 2. Technology } \\
\text { orientation }\end{array}$ & $82 \%$ & $59 \%$ & 1,58 \\
\hline 53 & $\begin{array}{l}\text { Complete identification of existing and new } \\
\text { customer requirements and needs. }\end{array}$ & InnoProcess & $\begin{array}{l}\text { 1. Market and } \\
\text { customer } \\
\text { orientation }\end{array}$ & $86 \%$ & $55 \%$ & 1,90 \\
\hline 54 & $\begin{array}{l}\text { Identification of the strongest product or service } \\
\text { characteristics with highest market potential or } \\
\text { market acceptance, to be able to set priorities } \\
\text { correctly. }\end{array}$ & InnoProcess & $\begin{array}{l}\text { 1. Market and } \\
\text { customer } \\
\text { orientation }\end{array}$ & $82 \%$ & $60 \%$ & 1,52 \\
\hline 55 & $\begin{array}{l}\text { Monitoring competitive activities in the market and } \\
\text { identification of the main competitive features. }\end{array}$ & InnoProcess & $\begin{array}{l}\text { 1. Market and } \\
\text { customer } \\
\text { orientation }\end{array}$ & $79 \%$ & $63 \%$ & 1,25 \\
\hline 56 & $\begin{array}{l}\text { Identification of new customer groups or new } \\
\text { markets for own know-how, technologies, products. }\end{array}$ & InnoProcess & $\begin{array}{l}\text { 2. Technology } \\
\text { orientation }\end{array}$ & $84 \%$ & $62 \%$ & 1,46 \\
\hline 57 & $\begin{array}{l}\text { Reasoned and detailed formulation of innovation } \\
\text { tasks or innovation strategies. }\end{array}$ & InnoProcess & $\begin{array}{l}\text { 5. Communication } \\
\text { and knowledge } \\
\text { management }\end{array}$ & $72 \%$ & $54 \%$ & 1,48 \\
\hline 58 & $\begin{array}{l}\text { Comprehensive problem solving and idea generation: } \\
\text { no valuable idea or solution is overlooked. }\end{array}$ & InnoProcess & 3. Creativity & $77 \%$ & $58 \%$ & 1,43 \\
\hline 59 & $\begin{array}{l}\text { Fast solving of particularly difficult technical } \\
\text { problems. }\end{array}$ & InnoProcess & 3. Creativity & $73 \%$ & $60 \%$ & 1,22 \\
\hline 60 & $\begin{array}{l}\text { Complete capturing of all employee ideas in every } \\
\text { step of product development }\end{array}$ & InnoProcess & $\begin{array}{l}\text { 5. Communication } \\
\text { and knowledge } \\
\text { management }\end{array}$ & $74 \%$ & $59 \%$ & 1,34 \\
\hline 61 & $\begin{array}{l}\text { Comprehensive collection and documentation of } \\
\text { ideas from customers, suppliers etc., following the } \\
\text { Open Innovation approach. }\end{array}$ & InnoProcess & $\begin{array}{l}\text { 1. Market and } \\
\text { customer } \\
\text { orientation }\end{array}$ & $71 \%$ & $54 \%$ & 1,44 \\
\hline 62 & $\begin{array}{l}\text { Error-free evaluation and objective selection of ideas } \\
\text { for implementation in new product concepts. }\end{array}$ & InnoProcess & $\begin{array}{l}\text { 5. Communication } \\
\text { and knowledge } \\
\text { management }\end{array}$ & $75 \%$ & $57 \%$ & 1,44 \\
\hline 63 & $\begin{array}{l}\text { Fast access to relevant new patent information such } \\
\text { as patent applications or patents worldwide. }\end{array}$ & InnoProcess & $\begin{array}{l}\text { 6. Risk and cost } \\
\text { management }\end{array}$ & $77 \%$ & $71 \%$ & 0,90 \\
\hline
\end{tabular}




\begin{tabular}{|c|c|c|c|c|c|c|}
\hline No. & Innovation Performance Parameters - IPP & Category & $\begin{array}{c}\text { Innovation } \\
\text { Indicator }\end{array}$ & $\begin{array}{c}\text { Imp. } \\
\text { Wi }\end{array}$ & $\begin{array}{c}\text { Sat. } \\
\text { Zi }\end{array}$ & $\begin{array}{l}\text { Rank. } \\
\text { pi [\%] }\end{array}$ \\
\hline 64 & $\begin{array}{l}\text { Well-structured and quickly accessible storage of } \\
\text { existing relevant patent information. }\end{array}$ & InnoProcess & \begin{tabular}{|l|} 
5. Communication \\
and knowledge \\
management
\end{tabular} & $72 \%$ & $65 \%$ & 0,99 \\
\hline 65 & $\begin{array}{l}\text { Early identification of technical problems and risks } \\
\text { in new ideas or innovation concepts. }\end{array}$ & InnoProcess & $\begin{array}{l}\text { 6. Risk and cost } \\
\text { management }\end{array}$ & $83 \%$ & $59 \%$ & 1,56 \\
\hline 66 & $\begin{array}{l}\text { Avoidance of possible organizational risks in the } \\
\text { execution of an innovation project or market launch, } \\
\text { such as financial misjudgements etc. }\end{array}$ & InnoProcess & $\begin{array}{l}\text { 6. Risk and cost } \\
\text { management }\end{array}$ & $77 \%$ & $58 \%$ & 1,44 \\
\hline 67 & $\begin{array}{l}\text { Early consideration of costs in the innovation } \\
\text { process, for example, during the idea or concept } \\
\text { assessment. }\end{array}$ & InnoProcess & $\begin{array}{l}\text { 6. Risk and cost } \\
\text { management }\end{array}$ & $69 \%$ & $65 \%$ & 0,96 \\
\hline 68 & $\begin{array}{l}\text { Systematic cost reduction in all steps of the } \\
\text { innovation process and new product development. }\end{array}$ & InnoProcess & $\begin{array}{l}\text { 6. Risk and cost } \\
\text { management }\end{array}$ & $65 \%$ & $62 \%$ & 0,97 \\
\hline 69 & $\begin{array}{l}\text { Rapid acquisition of information on a specific topic, } \\
\text { such as feasibility checks, search for suppliers or } \\
\text { know-how carriers, etc. }\end{array}$ & InnoProcess & $\begin{array}{l}\text { 5. Communication } \\
\text { and knowledge } \\
\text { management }\end{array}$ & $78 \%$ & $65 \%$ & 1,18 \\
\hline 70 & $\begin{array}{l}\text { Well-structured and easily accessible information on } \\
\text { all phases of the innovation process, from customer } \\
\text { needs analysis to ideation, design and market launch. }\end{array}$ & InnoProcess & \begin{tabular}{|l|} 
5. Communication \\
and knowledge \\
management
\end{tabular} & $72 \%$ & $54 \%$ & 1,49 \\
\hline 71 & $\begin{array}{l}\text { Repeatability of innovation projects at a high-quality } \\
\text { level, e.g. according to a defined procedure, } \\
\text { milestone system, etc. }\end{array}$ & InnoProcess & $\begin{array}{l}\text { 6. Risk and cost } \\
\text { management }\end{array}$ & $70 \%$ & $58 \%$ & 1,21 \\
\hline 72 & $\begin{array}{l}\text { Seamless information exchange and honest, } \\
\text { transparent communication in the innovation process } \\
\text { across departments, such as Marketing, R\&D, } \\
\text { Service etc. }\end{array}$ & InnoProcess & $\begin{array}{l}\text { 5. Communication } \\
\text { and knowledge } \\
\text { management }\end{array}$ & $84 \%$ & $55 \%$ & 1,86 \\
\hline 73 & $\begin{array}{l}\text { Low overall duration of innovation project, from the } \\
\text { definition of the goals and requirements to the } \\
\text { implementation of the product concept and market } \\
\text { launch. }\end{array}$ & InnoProcess & $\begin{array}{l}\text { 6. Risk and cost } \\
\text { management }\end{array}$ & $71 \%$ & $53 \%$ & 1,47 \\
\hline 74 & $\begin{array}{l}\text { Relevant information, e.g. about market situation, } \\
\text { technology or competitors is always up to date in any } \\
\text { phase of the innovation project. }\end{array}$ & InnoProcess & \begin{tabular}{|l|} 
5. Communication \\
and knowledge \\
management
\end{tabular} & $75 \%$ & $57 \%$ & 1,46 \\
\hline 75 & $\begin{array}{l}\text { Innovation projects are always completed in the } \\
\text { planned time, without interruptions or delays. }\end{array}$ & InnoProcess & $\begin{array}{l}\text { 6. Risk and cost } \\
\text { management }\end{array}$ & $58 \%$ & $47 \%$ & 1,29 \\
\hline 76 & $\begin{array}{l}\text { IP protection: the know-how developed in the } \\
\text { innovation projects cannot be copied by the } \\
\text { competition or indirectly used in a modified form. }\end{array}$ & InnoProcess & $\begin{array}{l}\text { 6. Risk and cost } \\
\text { management }\end{array}$ & $80 \%$ & $63 \%$ & 1,31 \\
\hline 77 & $\begin{array}{l}\text { The expected innovation outcomes and progress in } \\
\text { achieving set targets is monitored at all stages of the } \\
\text { innovation process. }\end{array}$ & InnoProcess & $\begin{array}{l}\text { 6. Risk and cost } \\
\text { management }\end{array}$ & $70 \%$ & $59 \%$ & 1,19 \\
\hline 78 & $\begin{array}{l}\text { Quick verification or feasibility check of new ideas } \\
\text { and innovation concepts, e.g. by prototyping. }\end{array}$ & InnoProcess & $\begin{array}{l}\text { 6. Risk and cost } \\
\text { management }\end{array}$ & $83 \%$ & $68 \%$ & 1,16 \\
\hline 79 & $\begin{array}{l}\text { Monitoring and management of the innovation } \\
\text { process with performance indicators, e.g. number of } \\
\text { patents, number of project interruptions, delays etc. }\end{array}$ & InnoProcess & $\begin{array}{l}\text { 6. Risk and cost } \\
\text { management }\end{array}$ & $61 \%$ & $48 \%$ & 1,37 \\
\hline 80 & $\begin{array}{l}\text { Quick and efficient solving of organizational } \\
\text { problems in the innovation process, e.g., resources } \\
\text { planning, personnel issues etc. }\end{array}$ & InnoProcess & 4. Leadership & $83 \%$ & $55 \%$ & 1,78 \\
\hline
\end{tabular}

Prof. Dr.-Ing. Pavel Livotov, Professor for Product Development and Engineering Design Offenburg University of Applied Sciences, Faculty of Mechanical and Process Engineering Badstr. 24, 77652 Offenburg, Germany Email: pavel.livotov@hs-offenburg.de 